\title{
Empire and the Right to Preach the Gospel in the School of Salamanca, 1535-1560
}

\author{
Daniel S. Allemann
}

'Dear father prior of the monastery of San Esteban in the city of Salamanca', wrote the Holy Roman Emperor Charles V in November 1539, 'I have been informed that certain religious masters of your house have debated and treated in their sermons and lectures the right we have over the Indies, the islands and firm lands in the oceanic sea. ${ }^{1}$ One very prominent member of the Dominican convent, whom Charles $\mathrm{V}$ had in mind when he composed this letter, was Francisco de Vitoria (1486-1546). ${ }^{2}$ Earlier in the same year, the prime chair in theology at the University of Salamanca had delivered his famous relectio De indis. In this solemn lecture, addressed to an illustrious audience of intellectuals, he engaged in the controversy about the 'barbarians in the New World, commonly called Indians, who came under the power of the Spaniards some forty years ago, having been previously unknown to our world' ${ }^{3}$

The attitudes to the Spanish conquest that Vitoria and his colleagues at Salamanca put forward have recently been subject to radically contrasting interpretations by historians of political thought and scholars associated with post-colonial studies, respectively. If we follow

\footnotetext{
* I would like to extend special thanks to Annabel Brett, for her invaluable feedback and guidance throughout the various stages of this article. I am also indebted to the journal's anonymous referees and to the audience of the Jahrestagung der Basel Graduate School of History, where an earlier version of the argument was presented in German. The research for this article began during my master's in Cambridge and has extended into my doctoral studies at the same place, and I am grateful for the support of the Jubiläumsstiftung der Basellandschaftlichen Kantonalbank and the Cambridge Commonwealth, European \& International Trust, respectively. In the text that follows, all translations are my own unless otherwise indicated.

${ }^{1}$ The letter by Emperor Charles V is edited as 'Carta al prior de San Esteban, Madrid, 10 de noviembre 1539', in El maestro fray Francisco de Vitoria: su vida, su doctrina e influencia, by Luis G. Alonso Getino (Madrid, 1930), p. 150: 'Venerable padre prior del monasterio de santisteban de la cibdat de salamanca yo he sydo ynformado que algunos maestros religiosos de esa casa han puesto en platica y tratado en sus sermones y en repeticiones del derecho que nos tenemos a las yndias yslas e tierra firme del mar oceano'.

${ }^{2}$ Belda Plans points out that Vitoria resided permanently in the Domincan convent of San Esteban during his time at Salamanca. See Juan Belda Plans, La escuela de Salamanca y la renovación de la teología en el siglo $X V I$ (Madrid, 2000), p. 326. Biographical information on the neo-scholastic theologians is, unless otherwise indicated, from Jacob Schmutz's excellent website Scholasticon, http://www.scholasticon.fr (accessed January 5, 2018).

${ }^{3}$ Francisco de Vitoria, De indis, in Vitoria: political writings, ed. and trans. Anthony Pagden and Jeremy Lawrance (Cambridge, 1991), p. 233.
} 
the latter, the Spanish theologians provided sophisticated vindications of Charles V's imperial cause, whereas, according to the former, they exposed instead that the emperor's venture overseas lacked a thorough foundation in justice. ${ }^{4}$ This article, however, tries to move beyond the apparently irreconcilable impasse that these clashing approaches might seem to constitute, by importing a post-colonial perspective into the toolbox of the intellectual historian. It suggests taking seriously the thrust of critical scholarship, while simultaneously making a case for assessing the language of the Salmantine theologians in its own terms and context. The result will be an alternative, novel lens through which to view contemporary responses to the shattering episode in world history that we know as the 'affair of the Indies'.

The sixteenth-century Spanish theologians, generally known as the 'School of Salamanca' or 'second scholastic', wrote extensive academic lectures and treatises on questions of justice and right first articulated in Thomas Aquinas's Summa theologiae. Alongside an array of sources ranging from Roman law to the medieval canon law tradition, they re-interpreted Aquinas's text in light of the theological, social, and political concerns of their time. Upon Charles's election as Holy Roman Emperor in 1519 and the expansion of Spain's composite empire, a whole range of issues regarding political authority became central to their thought and literary production. Ever since James Brown Scott's recovery of Vitoria's lecture on the American Indians in the early twentieth century, it is one specific political context which has remained a most prominent focus of historical scholarship on the second scholastic: the Spanish conquest of the New World..$^{5}$ In what is arguably the most well-known study on this subject, Anthony Pagden showed that Vitoria, in particular, repudiated the idea that the Amerindians could be justly dispossessed and dominated by the Spaniards because they were Aristotle's 'slaves by nature'. ${ }^{6}$ It does not therefore come as a

\footnotetext{
${ }^{4}$ For a recent intellectual history perspective, see e.g. Andrew Fitzmaurice, Sovereignty, property and empire, 1500-2000 (Cambridge, 2014), ch. 2. The most well-known post-colonial reading is Antony Anghie's Imperialism, Sovereignty and the making of international law (Cambridge, 2004), ch. 1. We shall return to both these studies.

${ }^{5}$ James Brown Scott, The Spanish origins of international law: Francisco de Vitoria and his law of nations (Oxford, 1934). See also Luciano Vicente Pereña, Misión de España en América: 1540-1560 (Madrid, 1956); Lewis Hanke, Aristotle and the American Indians: a study in race prejudice in the modern world (Bloomington, IN, 1959); Bernice Hamilton, Political thought in sixteenth-century Spain: a study of the political ideas of Vitoria, De Soto, Suárez, and Molina (Oxford, 1963); Jaime Brufau Prats, La escuela de Salamanca ante el descubrimiento del nuevo mundo (Salamanca, 1989). Notable exceptions are Quentin Skinner, who has situated the thought of the School of Salamanca in the context of the intellectual battles the neo-scholastics fought with humanists and Lutherans in post-Reformation Europe, and Annabel Brett, in her first monograph, which focuses on the neo-scholastic theorization of individual rights. See Quentin Skinner, The foundations of modern political thought, (2vosl., Cambridge, 1978), II, pp. 135-73; and Annabel S. Brett, Liberty, right and nature: individual rights in later scholastic thought (Cambridge, 1997), ch. 4.

${ }^{6}$ Anthony Pagden, The fall of natural man: the American Indian and the origins of comparative ethnology, 2nd rev. ed. (Cambridge, 1986), chs. 2-4. As Brian Tierney has shown, however, the Salmantine theologians
} 
surprise that the emperor was far from content with Vitoria's critical appraisal of the conquest. In the final passage of the above-mentioned letter, Charles $\mathrm{V}$ ordered that the Dominican professors 'neither now nor at any other time address, preach, or dispute about this issue again, and that they neither publish anything in writing relating to this matter without the express license of us'.

But can the Salmantine university theologians really be said to have seriously challenged the legitimacy of Spain's possessions in the Americas? Recent studies from the discipline of intellectual history indeed suggest just this. In the wake of a growing interest in the legacy of the ideological foundations both of constructions and deconstructions of European imperial claims, the School of Salamanca has become the subject of histories of 'empire'. Focusing on the neo-scholastic engagement with the ideology, history, and legal foundations of Roman imperium, intellectual historians have shown that almost all the Salmantine professors repudiated the notion that Charles V could licitly claim authority over the Indies with recourse to his title as Roman emperor. ${ }^{8}$ But it is well worth remembering that the scholastics were not just academic lecturers and teachers, and equally served as ecclesiastical and political advisors to the highest Castilian authorities. This is true even for Vitoria, whose undeniable tensions with the emperor we have already encountered. But Vitoria nevertheless enjoyed the 'great admiration' of Charles V, who once paid a personal visit to one of Vitoria's classes and later envisaged him to be among his ambassadors at the Council of Trent (1545-63). ${ }^{9}$ How, then, are we to think of the relationship between Salamanca and the Spanish empire? In what follows, this article shifts our attention away from an exclusively Roman understanding of empire towards the ius praedicandi, the right to preach the gospel. Although the ius praedicandi has been sorely neglected in modern historiography, it constituted a central locus for engagements of the School of Salamanca with the conquest. It negotiated an uneasy and ambiguous interface between nature and the Christian faith, and the ultimate effect of accepting the validity and force of this right, I will

redefined rather than outrightly rejected the Aristotelian natural slavery theory. See Brian Tierney, 'Aristotle and the American Indians - again: two critical discussions', Cristianesimo nella storia, 12 (1991), pp. 311-15; and Tierny, The idea of natural rights: studies on natural rights, natural law, and church law, 1150-1625 (Atlanta, 1997), p. 270.

${ }^{7}$ Emperor Charles V, 'Carta al prior de San Esteban', p. 151: 'mandarles [i.e., the religious masters] eys de nuestra parte y vuestra que agora ni en tiempo alguno sin espresa licencia nuestra no traten ni prediquen ni disputen de lo suso dicho ni hagan ymprimir escriptura alguna tocante a ello'.

${ }^{8}$ A discussion of the respective studies follows below in Section One.

${ }^{9}$ Vitoria's failing health, however, required him to remain in Salamanca. See Belda Plans, La escuela de Salamanca, pp. 331-2. 
argue, was not only a justification of the Spanish presence in the New World, but also of Charles V's imperial venture.

\section{I}

In recent histories of 'empire', it is particularly the Dominican scholastic that has become the centre of inquiry, for the writings of its most well-known exponents, Francisco de Vitoria and Domingo de Soto (1495-1560), were in important ways responses to the Charles V's pursuit of empire in the Indies. Scholars have shown that classical Rome provided a decisive reference point in Spanish scholastic evaluations of the conquest of America from two related but ultimately distinct perspectives. The first is what we might call the 'ideology of Rome' and centred on the question of how the Roman imperial tradition might or might not grant the Spaniards rights over Amerindian lands and peoples. Francisco de Vitoria's answer was ambiguous. ${ }^{10}$ In his discussion of the potential justifications of Castilian domination overseas in De indis, Vitoria explained that a licit 'title may arise whenever the barbarians themselves are engaged in legitimate war with one another ... and may call upon the Spaniards to help them, and then share the prizes of victory with them' ${ }^{11}$ As allies and friends, the Spaniards could have joined forces with a native commonwealth, supporting its belligerent undertaking against another, hostile Amerindian city. That it was an explicitly Roman notion that underlay this example was apparent for Vitoria. 'The confirmation of this', he argued, 'is provided by the Romans, who extended their empire in just this way ... thereby taking possession of new provinces by the laws of war.' ${ }^{12}$ Vitoria here pointed to conquistador Cortés' pact with the Nahua indios of Tlaxcala which, in his view, seemed to provide evidence for a Spanish actualization of Roman imperialism in the New World. ${ }^{13}$

\footnotetext{
${ }^{10}$ The most sophisticated discussion of Vitoria's use of the Roman imperial tradition is available in David A. Lupher, Romans in a New World: classical models in sixteenth-century Spanish America (Ann Arbor, MI, 2003), pp. 68-82.

${ }^{11}$ Vitoria, De indis, trans. Pagden and Lawrance, q. 3, a. 7, p. 289.

${ }^{12}$ Ibid.

${ }^{13}$ Vitoria, De indis, trans. Pagden and Lawrance, q. 3, a. 7, p. 289. See the discussion in Lupher, Romans in a New World, pp. 73-7. For insightful reflections on the contested contemporary conception of the pact's afterlife in the context of the Tlaxalan subjection to Spanish suzerainty, see Lauren Benton and Adam Clulow, 'Empires and protection: making interpolity law in the early modern world', Journal of Global History, 12 (2017), pp. 7492, at p. 87. On the nexus between treaty-making and empire, see also Saliha Belmessous, 'The paradox of an empire by treaty', in Empire by treaty: negotiating european expansion, 1600-1900, ed. by Saliha Belmessous (Oxford, 2015), pp. 1-18.
} 
In contrast, it has been pointed out that for Vitoria's colleague Domingo de Soto, the ideology of Rome could not possibly provide a justificatory model for the conquest. ${ }^{14}$ In a central passage of his lecture De dominio (1535), Soto inquired 'whether the emperor is lord of the whole world'15 and could for this reason legitimately claim authority over the newly discovered lands in the Americas. He conceded that the Romans had indeed dominated large parts of the Western world and passed on this historical jurisdiction to Charles V. But he also posited that 'the Romans could not give to the emperor what they did not have themselves; but they never had imperium over the whole world and at no point in history made it to the antipodes or lands that are currently being discovered'. ${ }^{16}$ Unlike Vitoria, then, Soto pushed back against the idea that the Roman imperial tradition might in any way provide a legal foundation for Spanish empire overseas, and Charles V ultimately had 'no right or dominion whatsoever over the lands of the unbelievers' ${ }^{\prime 17}$ by virtue of his title as Holy Roman Emperor.

A second, further way in which the neo-scholastics turned to Rome, and which has likewise been recovered by intellectual historians, is how they appropriated arguments from Roman law in their appraisals of the Spanish conquest. ${ }^{18}$ Viewed through this lens, the Salmantine responses to Charles V's venture overseas were fundamentally and unanimously critiques of empire. Vitoria and Soto, above all, resolutely repudiated the idea that the New World had been previously 'unoccupied' property and had thus been up for grabs for the Spaniards, as first takers. ${ }^{19}$ Extending the originally private Roman law sense of occupatio (as an individual's rightful acquisition of a previously unowned thing) into the public domain, Vitoria and Soto insisted that the Amerindians had 'occupied' their lands long before the

\footnotetext{
${ }^{14}$ Anthony Pagden, Lords of all the world: ideologies of empire in Spain, Britain and France c.1500-c.1800 (New Haven, CT, 1995), pp. 50-2; Richard Tuck, The rights of war and peace: political thought and the international order from Grotius to Kant (Oxford, 1999), pp. 73-5; Lupher, Romans in a New World, pp. 61-8 and pp. 93-8; Annabel S. Brett, 'Scholastic political thought and the modern concept of the state', in Rethinking the foundations of modern political thought, ed. Annabel S. Brett and James Tully with Holly HamiltonBleakley (Cambridge, 2006), pp. 144-5; Lauren Benton and Benjamin Straumann, 'Acquiring empire by law: from Roman doctrine to early modern European practice', Law and History Review, 28 (2010), pp. 1-38, at pp. 23-5; Fitzmaurice, Sovereignty, property and empire, p. 46; and Anthony Pagden, The burdens of empire: 1539 to the present (Cambridge, 2015), pp. 52-3.

${ }^{15}$ Domingo de Soto, De dominio, Latin ed. with parallel Spanish trans. by Jaime Brufau Prats, in: Domingo de Soto: relección "De Dominio", ed. and trans. with an introduction by Jaime Brufau Prats (Granada, 1964), p. 134: 'Sequitur secundum dubium potissimum in hac nostra relectione: An videlicet Imperator sit dominus totius orbis.'

${ }^{16}$ Ibid., p. 152: 'Nam romani non potuerunt dare Imperatori nisi quod habebant; sed romani numquam habuerunt Imperium totius orbis, numquam enim memoriae traditum est pervenisse romanos ad antipodas vel ad has terras quae modo inveniuntur.'

${ }^{17}$ Ibid., p. 158: 'Ex his sequitur quod Imperator ad terras infidelium nullum ius habet nec dominium.'

${ }^{18}$ For excellent discussions of this perspective, see Benton and Straumann, 'Acquiring empire by law', pp. 20-5; and Fitzmaurice, Sovereignty, property and empire, pp. 40-48.

${ }^{19}$ Vitoria, De indis, trans. Pagden and Lawrance, q. 2, a. 3, pp. 264-5; Soto, De dominio, p. 162.
} 
Spanish arrival and thus possessed legitimate jurisdiction, or sovereignty, over their territories. In this sense, the neo-scholastics exploited Roman law dicta on occupation that in their handling came to provide a barrier to any straightforward vindication of the Spanish overseas empire.

Recent post-colonial studies, on the other hand, have forcefully stressed the entanglement of neo-scholastic theologians, especially Francisco de Vitoria's, in the Spanish imperial and colonial venture overseas. ${ }^{20}$ The most influential case has been made by Antony Anghie, a legal scholar whose work has decisively shaped the ways in which we today conceptualize "the historical relationship between international law and the "Third World"' ${ }^{21}$ His approach is post-colonial in the sense that he seeks to expose how 'the colonial origins of international law' ${ }^{22}$ have extended well beyond the age of colonialism - and he locates the earliest traces of this nexus between Western hegemony and law in Francisco de Vitoria's lecture De indis. Anghie focuses on Vitoria's use of the ius gentium or 'law of nations' and, in particular, on the implications of Vitoria's insistence of a so-called right of free communication (ius communicandi). Although after the Fall from Eden, human beings set up distinct kingdoms and divided the formerly common lands on earth, Vitoria argued that certain things such as 'running water and the open sea, rivers and ports are the common property of all' ${ }^{23}$ Importantly, this right of inter-communication equally extended to trade relations, which effectively meant that everybody could licitly enter foreign commonwealths for commercial purposes. The Spaniards, Vitoria insisted, 'may import the commodities which they lack, and export the gold, silver, or other things which [the Amerindians] have in abundance' ${ }^{24}$ It was illicit for native rulers to interfere with this freedom, in the same way that the king of France could neither prevent Castilian merchants from 'travelling or even living in France, or vice versa, so long as it caused no sort of harm to themselves' ${ }^{25}$ For Anghie, however, this juridical framework is only equal and reciprocal on the surface: 'Vitoria's apparently innocuous enunciation of a right to "travel" and "sojourn" extends

\footnotetext{
${ }^{20}$ Robert A. Williams Jr., The American Indian in western legal thought: the discourses of conquest (Oxford, 1990), ch. 2; China Miéville, Between equal rights: a Marxist theory of international law (Chicago, IL, 2006), ch. 5; and above all, Anghie, Imperialism, sovereignty and the making of international law, ch. 1.

${ }^{21}$ Anghie, Imperialism, sovereignty and the making of international law, p. 3. The movement of scholars engaged in the examination of this nexus is generally known as 'Third World Approaches to International Law (TWAIL)'. See e.g. Bhupinder S. Chimni, 'Third world approaches to international law: a manifesto', International Community Law Review, 8 (2006), pp. 3-27.

${ }^{22}$ Anghie, Imperialism, sovereignty and the making of international law, p. 3.

${ }^{23}$ Vitoria, De indis, trans. Pagden and Lawrance, q. 3, a. 1, p. 279.

24 Ibid.

${ }^{25}$ Ibid., p. 278.
} 
finally to the creation of a comprehensive, indeed inescapable system of norms which are inevitably violated by the Indians. ${ }^{26}$

Anghie's focus on Vitoria's theorization of the law of nations provides a stark contrast to the earlier Pagdenian focus on the natural constitution and abilities of human beings and reorients our attention towards an essentially legal perspective. But while this arguably also applies to the Roman lenses mentioned above, Anghie's understanding of empire differs significantly from the conceptions that emerge from either 'the ideology of Rome' or 'occupation'. He insists that we miss what is at the heart of Vitoria's thought if we simply focus on how he revived and redeployed classical legal doctrines. Quite the contrary, Anghie insists that Vitoria's law of nations was 'created out of the unique issues generated by the encounter between the Spanish and the Indians'. ${ }^{27}$ The result, for Anghie, is a novel and distinct articulation of empire that 'finally endorses and legitimizes endless Spanish incursions into Indian society' ${ }^{28}$ and leads to an 'endless process of creating a gap between two cultures, demarcating one as "universal" and civilized and the other as "particular" and uncivilized' ${ }^{29}$

While Anghie's assessment might indeed seem plausible at first sight, it is in fact too forceful as it stands and does not fully do justice to the complexity of how either Vitoria or his colleagues at Salamanca understood and deployed the ius gentium. Vitoria's construction of an image of 'uncivilized' American Indians does not always so clearly go hand in hand with a juridical articulation of Spanish domination. As Annabel Brett has shown, Vitoria's insistence that 'these barbarians are by nature cowardly, foolish, and ignorant' ${ }^{30}$ did not therefore give the Spaniards a blank cheque to wage war against American Indians. ${ }^{31}$ Quite the contrary, Vitoria argued that because Amerindians were 'understandably fearful of men whose customs seem so strange ... the Spaniards must take care for their own safety, but do so with as little harm to the barbarians as possible since this is a merely defensive war'. ${ }^{32}$ What is more, the neo-scholastics insisted that the rights granted to human beings by natural

\footnotetext{
${ }^{26}$ Anghie, Imperialism, sovereignty and the making of international law, p. 21.

${ }^{27}$ Ibid., p. 15, emphasis mine.

${ }^{28}$ Ibid., p. 21.

${ }^{29}$ Ibid., 4. The same argument has recently been reiterated by José-Manuel Barreto, who closely follows Anghie's line of argument. See Barreto, 'Imperialism and decolonization as scenarios of human rights history', in Human rights from a Third World perspective, ed. José-Manuel Barreto (Newcastle upon Tyne, 2013), p. 149.

${ }^{30}$ Vitoria, De indis, trans. Pagden and Lawrance, q. 3, a. 1, p. 282.

${ }^{31}$ Annabel S. Brett, Changes of state: nature and the limits of the city in early modern natural law (Princeton, NJ, 2011), p. 15n19. Brett has also shown that the ius communicandi became equally relevant in a European context, granting mendicants the right to freely communicate between cities in the old world (ibid., pp. 34-5). ${ }^{32}$ Vitoria, De indis, trans. Pagden and Lawrance, q. 3, a. 1, p. 282, emphasis mine.
} 
law and by the ius gentium, ${ }^{33}$ although ultimately derived from God, did not depend on God's grace. Instead, the Spanish scholastic theologians - including Vitoria ${ }^{34}$ - insisted that all human beings, by virtue of their humanity, not their Christianity or culture, possessed these rights..$^{35}$

The sweeping post-colonial critiques of the School of Salamanca's universalistimperial complicity, then, risk overriding the categories that the Salmantine theologians themselves used ${ }^{36}$ At the same time, however, it is important to point out that none of the Spanish scholastic theologians seriously challenged the legitimacy of the Spanish presence in the New World, as Martti Koskenniemi rightly insists. ${ }^{37}$ We should not therefore simply dismiss the readings by Anghie and others, but instead engage with the broader implications they entail. When it comes to Vitoria, some of the intellectual historians focusing on the discourse of imperium, most notably David Lupher, indeed emphasize that Vitoria can plausibly be interpreted as an 'apologist for Spanish imperialism' ${ }^{38}$ The problem, however, is that if we solely focus on Roman arguments we do end up with the conclusion that apart from Vitoria, the vast majority of the Spanish scholastic theologians, such as Domingo de Soto, Bartolomé Carranza de Miranda (1503-76), or Melchor Cano (1509-60) were critics of Spanish imperialism. ${ }^{39}$

Instead of asking whether a given scholastic theologian was anti- or pro-imperial in a strictly Roman sense, I wish to adopt from recent post-colonial approaches to the School of Salamanca the awareness that empire is not solely articulated in and through traditional ideological and legal commonplaces. In other words, I concur that the question of how the

\footnotetext{
${ }^{33}$ The ius gentium served to mediate the demands of natural law into the concrete state of human political affairs after the Fall and was thus intimately bound up with the teleology of nature and God's creation. See Annabel S. Brett, 'Human rights and the Thomist tradition', in Revisiting the origins of human rights, ed. Pamela Slotte and Miia Halme-Tuomisaari (Cambridge, 2015), p. 91. See also Brett, Changes of state, ch. 1.

${ }^{34}$ Vitoria, De indis, trans. Pagden and Lawrance, q. 1, conclusion, p. 250: 'the barbarians undoubtedly possessed as true dominion, both public and private, as any Christians'.

${ }^{35}$ See Skinner, The foundations, II, pp. 67-9; Pagden, Fall of natural man, pp. 29-39; Anthony Pagden and Jeremy Lawrance, 'Introduction', in Vitoria: political writings, ed. and trans. Anthony Pagden and Jeremy Lawrance (Cambridge, 1991), p. xvi; and Felix Hafner, Adrian Loretan, and Christoph Spenlé, 'Naturrecht und Menschenrecht: Der Beitrag der Spanischen Spätscholastik zur Entwicklung der Menschenrechte', in Die Ordnung der Praxis: Neue Studien zur Spanischen Spätscholastik, ed. Frank Grunert and Kurt Seelmann (Tübingen, 2001), p. 141.

${ }^{36}$ On this point, see also Ian Hunter, 'Global justice and regional metaphysics: on the critical history of the law of nature and nations', in Law and politics in British colonial thought: transformations of empire, ed.

Shaunnagh Dorsett and Ian Hunter (Basingstoke, 2010), pp. 11-29. For a counter-perspective, see Anne Orford, 'The past as law or history? The relevance of imperialism for modern international law', International Law and Justice Working Papers, 2 (2012), pp. 1-17.

${ }^{37}$ Martti Koskenniemi, 'Empire and international law: the real Spanish contribution', University of Toronto Law Journal, 61 (2011), pp. 1-36, at p. 11.

${ }^{38}$ Lupher, Romans in a New World, p. 81.

${ }^{39}$ I shall engage with the paricular scholarly interpretations of these neo-scholastic theologians below.
} 
Spanish theologians articulated hegemonic domination cannot be answered solely by looking for empire where we most readily expect to find it. Of course, this requires as a premise that we abandon an understanding of a strictly Roman notion of empire and, instead, conceive it more generally as the Spanish imposition of authority in the New World. However, I do not thereby intend to dismiss the crucial importance of the legal implications of empire..$^{40}$ Instead, I wish to take into account neo-scholastic theorizations of empire and authority that are not necessarily Roman in origin, but which eventually lead to the same articulation of a legally binding power over the lands and peoples in America which ultimately granted the Spaniards the same as imperium, namely, in Theodor Mommsen's words, 'the right to demand obedience'. ${ }^{41}$

The answer to this question - how they did it - is by no means straightforward. After all, the neo-scholastic theologians, as noted above, all insisted that natural rights ${ }^{42} \mathrm{did}_{\text {not }}$ depend on God's grace, and they could not therefore easily justify Spanish authority over American Indians. However, I wish to show that shifting the focus to neo-scholastic theorizations of the right to preach the gospel, the ius praedicandi, allows us to conceive the engagement of Spanish scholastic theologians in the 'affair of the Indies' in a new light. ${ }^{43}$ This alternative line of analysis does justice to the legalistic nature of neo-scholastic writings without reducing their venture to a discourse on Roman imperium. At the same time, it equally acknowledges the implications of recent post-colonial scholarship without glossing over the historical contingency of the language in which the scholastics were articulating their claims. Ultimately, the question this article seeks to address is how the ius praedicandi

\footnotetext{
${ }^{40}$ Although Rudolf Walther, in his article on Imperialismus in the Geschichtliche Grundbegriffe, stresses that the notion of empire always also encompassed various non-legal significations. See Rudolf Walther, 'Imperialismus', in Geschichtliche Grundbegriffe: Historisches Lexikon zur politisch-sozialen Sprache in Deutschland, ed. Otto Brunner et al. (8 vols., Stuttgart, 1972-97), III, p. 171: “'Imperium” war primär stets ein rechtlich mehr oder weniger genau bestimmter Begriff, dem daneben auch verschiedene nichtrechtliche Bedeutungen zukamen.'

${ }^{41}$ Theodor Mommsen, Abriss des römischen Staatrechts, 2nd ed. (Leipzig, 1907), p. 91: 'Das Imperium, das Recht Gehorsam zu fordern'. For an excellent history of the concept of imperium, see also J.S. Richardson, 'Imperium Romanum: empire and the language of power', in Theories of empire, 1450-1800, ed. David Armitage (Aldershot, 1998), pp. 1-9. For a recent account on current historiographical debates about empire that comes with an extensive bibliography, see Sophus A. Reinert, 'Wars and empires', in A companion to intellectual history, ed. Richard Whatmore and Brian Young (Malden, MA, 2016), pp. 402-16.

${ }^{42}$ For the remainder of this article, I will not distinguish natural rights from rights granted by the ius gentium, for the point will always be to draw a contrast between the language of natural law, on the one hand, and the language of grace and the faith, on the other.

${ }^{43}$ Another alternative approach has recently been suggested by the legal scholar Martti Koskenniemi, who argues that the 'real Spanish contribution' was the neo-scholastics' theorization of private rights that ultimately led to a form of inter-individual, commercial imperialism. A thorough engagement with Koskenniemi's argument is, however, beyond the scope of this article, whose focus remains on public rights and jurisdiction. See Koskenniemi, 'Empire and international law', passim.
} 
was creatively exploited by Spanish scholastic theologians in order to negotiate a largely neglected but fundamental interface between two discourses that are commonly regarded as distinct: the language of natural rights, on the one hand, as independent of God's grace, and the hegemonic conception of the Christian faith and culture, on the other hand, as independent of any strictly legal consequences. Much of modern scholarship has rightly emphasized the neo-scholastic's separation of questions of rights from questions of the faith. However, it is exactly the ius praedicandi where this separation breaks down.

\section{II}

The neo-scholastic discussions of the ius praedicandi are in important ways extensions of and commentaries on Aquinas's reflections on preaching. In the Secunda secundae of his Summa theologiae, Aquinas addressed the question 'whether unbelievers ought to be coerced into the faith' ${ }^{44} \mathrm{He}$ argued that although unbelievers 'are in no way to be compelled into the faith ... they should be coerced by the faithful lest they hinder the faith' ${ }^{45}$ Moreover, Aquinas also claimed that even though unbelievers had rightful authority over their territories, their 'right of dominion or authority can be justly abolished by the sentence or ordinance of the Church'. ${ }^{46}$ The matter became more complicated, however, when addressing the situation of so-called non-apostate infidels, that is, unbelievers who were not and had never been subject to Christian domination ${ }^{47}$ - a categorization of unbelievers that only became possible in the context of the 'discovery' of the New World and which was first articulated by Tommaso de Vio Cajetan (1468-1534). ${ }^{48}$ In his lecture course on Aquinas's Secunda secundae at Salamanca in 1534-5, Vitoria endorsed Aquinas's position insofar as he agreed that 'Christian princes have the authority to compel their subjects to believe'. ${ }^{99}$ When it came to non-apostate unbelievers, on the other hand, Vitoria argued that this did not apply, 'because the king of Spain has no greater power over them than I do over my fellow citizens; but I cannot compel a fellow citizen to hear mass, ergo'.$^{50}$

\footnotetext{
${ }^{44}$ Thomas Aquinas, Summa theologiae, 2a2ae, q. 10, a. 8, p. 268. I am using the following translation: Thomas Aquinas, Aquinas: political writings, ed. and trans. Robert W. Dyson (Cambridge, 2002).

${ }^{45}$ Ibid.

${ }^{46}$ Ibid., a. 10, p. 271.

${ }^{47}$ Note that the neo-scholastic critique of Roman imperium is equally based on this issue, for the New World lies outside the traditional realm of the Christian-Roman world.

${ }^{48}$ Hafner, Loretan, and Spenlé, 'Naturrecht und Menschenrecht', pp. 130-1.

${ }^{49}$ Francisco de Vitoria, Lectio reportata in ST II-II 10.8, ed. and trans. as 'Lecture on the evangelization of unbelievers', in Vitoria: political writings, ed. and trans. Anthony Pagden and Jeremy Lawrance (Cambridge, 1991), p. 344.

${ }^{50}$ Ibid., p. 346.
} 
In his 1539 lecture on the American Indians, Vitoria famously rejected the legal force of the bulls that Pope Alexander VII had issued for the Catholic Monarchs. 'The pope has no temporal power over these barbarians' ${ }^{51}$ and his donation provided 'no right at all to occupy their countries' ${ }^{52}$ in Vitoria's view. Crucially, however, this did not mean that the remainder of De indis solely centred on 'secular' issues, and that questions of religion and the faith were off the table. ${ }^{53}$ Vitoria also reiterated Aquinas's dictum that 'Christians have the right to preach and announce the Gospel' ${ }^{54}$ and 'if the barbarians ... obstruct the Spaniards in their free propagation of the Gospel, the Spaniards, after first reasoning with them to remove any cause of provocation, may preach and work for the conversion of that people even against their will, and may if necessary take up arms and declare war on them' ${ }^{55}$ This clearly shows that notwithstanding his weakening of the papal donation, and despite his initial denial of the possibility to forcibly convert American Indians, Vitoria conceived the ius praedicandi as a fundamental right whose prevention gave rise to the purely natural right of waging war to the Spaniards. ${ }^{56}$ It would therefore be misleading to suggest that 'for Vitoria ... there was no justification for the conquest' ${ }^{57}$ as Andrew Fitzmaurice has claimed. But it also seems strange to view Vitoria's 'questioning of the jurisdiction of the papacy' as his principal achievement, and to conclude from this that his intervention led to 'a significant shift in the theory of legitimate imperialism, weakening the simple connection between the spread of the Gospel and a supposed right to conquer', ${ }^{58}$ as Joan-Pau Rubiés has recently argued. Quite the contrary, the ius praedicandi provided a powerful way of translating Vitoria's insistence on the absolute truth of Christianity into the language of natural law.

It is to the merit of scholars such as Richard Tuck and David Lupher that the ubiquitous and sole focus on Vitoria's De indis has recently been complemented by a recovery of the perspective that Domingo de Soto, Vitoria's pupil and later colleague at Salamanca, presented in his immediate response to the 'affair of the Indies' in his 1535

\footnotetext{
${ }^{51}$ Vitoria, De indis, q. 2, a. 2, p. 262, original emphasis.

${ }^{52}$ Ibid., p. 264.

${ }^{53}$ Vitoria remained ambiguous as to whether there was a connection between papal power and the right to preach, whereas Domingo de Soto established an intimate connection between the two, as we shall see below.

${ }_{54}$ Ibid., q. 3, a. 2, p. 284, original emphasis.

55 Ibid., p. 285, original emphasis.

${ }^{56}$ See also Daniel Deckers, Gerechtigkeit und Recht: Eine historisch-kritische Untersuchung der Gerechtigkeitslehre des Francisco de Vitoria (1483-1546) (Freiburg i. B., 1991), pp. 239-40.

${ }^{57}$ Fitzmaurice, Sovereignty, property and empire, pp. 48-9.

${ }^{58}$ Joan-Pau Rubiés, 'The discovery of new worlds in sixteenth-century philosophy', in The Routledge companion to sixteenth-century philosophy, ed. Henrik Lagerlund and Benjamin Hill (New York: Routledge, 2017), p. 72. For a similar argument, see also James Muldoon, Popes, lawyers, and infidels: the church and the non-Christian world, 1250-1550 (Philadelphia: University of Pennsylvania Press, 1979), pp. 148-50.
} 
lecture De dominio..$^{59}$ Both Tuck and Lupher draw attention to Soto's insistence 'that the emperor in no way has dominium of all the world' ${ }^{60}$ However, it is less clear that Soto therefore also rejected an enforceable ius praedicandi. In the final and central passage of $D e$ dominio, Soto stated that

in the Gospel, we find: Go preach the Gospel to all creatures (Mark 16); where the right to preach the Gospel (ius praedicandi) all over the world is granted to us, and as a consequence, we are given the right to defend ourselves against whomever that impedes our preaching. ... But I have not said this in order to condemn everything that has been done [by the Spaniards] among these Caribbean Indians, for the judgements of God are unfathomable, and God perhaps wants to convert so many peoples in a way unknown to us. ${ }^{61}$

Rather than comprising 'a bold challenge to the legitimacy of Spanish dominion in the Indies', ${ }^{62}$ as David Lupher has characterized Soto's lecture, an attention to the final words in De dominio leaves the reader with a conclusion that is far from straightforward. Indeed, Soto emphasized that he did not know 'by what right we retain the ultramarine empire that has recently been discovered'. ${ }^{63}$ However, he equally insisted on the validity of the ius praedicandi as a right that could be defended, and he was very explicit that he did not condemn the Spaniards' presence and all their deeds in the New World. Soto did not therefore 'reject the possibility of conquest' and he neither argued that 'the attack on preachers seen in the Amerindian case cannot be a legitimate cause for conquering peoples' ${ }^{64}$ as the theologian David Lantigua forcefully claims. Rather, in De dominio, Soto remained ambiguous as to whether the ius praedicandi was indeed the right which could have provided

\footnotetext{
${ }^{59}$ It must be noted, however, that in Spanish scholarship Soto's De dominio was received and discussed already in the early 1960. See especially Jaime Brufau Prats' El pensamiento político de Domingo de Soto y su concepción del poder (Salamanca, 1960); and also his Domingo de Soto: relección "De Dominio" (Granada, 1964), in which the Latin text with parallel Spanish translation of Soto's lecture is edited.

${ }^{60}$ Soto, De dominio, p. 162: 'quod Imperator nulla via habet Imperium in toto orbe'. For references to Tuck and Lupher, see above at footnote 14.

${ }^{61}$ Soto, De dominio, p. 162: 'In Evangelio habemus: Ite praedicate Evangelium omni creaturae, Mc. 16; ubi datum est nobis ius praedicandi ubique terrarum et, ex consequenti, datum est nobis ius defendendi nos a quibuscumque nos impedirent a praedicatione. ... Nec ista dixerim ad condemnandum omnia quae fiunt apud istos insulares; nam iudicia Dei abyssus multa, et Deus forsam vult tot gentes via nobis ignota ad se convertere.' ${ }^{62}$ Lupher, Romans in a New World, p. 62.

${ }^{63}$ Soto, De dominio, p. 162: 'Quo ergo iure retinemus Imperium quod modo reperitur ultramarinum? Re vera ego nescio.'

${ }^{64}$ David Lantigua, 'The freedom of the gospel: Aquinas, subversive natural law, and the Spanish Wars of religion', Modern Theology, 31 (2015), pp. 312-37, at p. 330.
} 
a legitimation of Spanish authority over American Indians, and it is only in a much later text that he came to take a more comprehensively articulated stance. But before considering Soto's later writing, let us first turn to Bartolomé Carranza de Miranda, who addressed the implications of the ius praedicandi in his lecture course on Aquinas's Summa in 1540.

Although Carranza was never himself actively involved in the University of Salamanca, he had strong ties to various theologians at Salamanca, commented on the same passages of Aquinas, and relied on the same sources as his colleagues. He attended Vitoria's early lectures at the Dominican Colegio de San Gregorio in Valladolid around the mid-1520s, became a close friend of Domingo de Soto's, and assumed the prime chair in theology at Valladolid in $1536 .{ }^{65}$ A major reason why Carranza nevertheless remains largely absent from scholarly discussions of neo-scholastic thought is that his lectures on the Summa were never turned into a publication and exist only in manuscript, with the exception of the edition of his commentary on question 10 of the Secunda secundae. ${ }^{66}$ And it is exactly in this section that Carranza addressed the implications of the ius praedicandi in the context of the New World.

Carranza first asserted that American Indians were true masters of their own affairs and could not therefore, on behalf of their unbelief, be subjected either by the emperor or by the pope. ${ }^{67} \mathrm{He}$ thereby not only followed Soto in unambiguously rejecting the Roman imperial title, but he equally reiterated the authentically neo-Thomist separation of rights from grace. With regard to the ius praedicandi, Carranza went on to argue that

the prince of the infidels cannot be compelled to listen to the faith ... if the entire commonwealth agreed that they do not want to hear about another faith or any laws

\footnotetext{
${ }^{65}$ General biographical information on Carranza is from Schmutz's entry on Carranza on Scholasticon; and from Pereña's Misión de España in América, pp. 27-31. For Vitoria and Carranza, see Lupher, Romans in a New World, p. 40; and Pereña, Misión de España en América, 31. For Soto and Carranza, see Belda Plans, La escuela de Salamanca, p. 543.

${ }^{66}$ Carranza's commentary on q. 10 of the 2a2ae is edited, with parallel Spanish translation, as Ratione fidei potest Caesar debellare et tenere Indos novi orbis? in Misión de España en América: 1540-1560, by Luciano Pereña (Madrid, 1956), pp. 38-57. As Pereña states in the first footnote to the edited text, this section is a part of a manuscript in the Vatican library that is entitled Annotationes in 2am 2ae D. Thomae. Carranza is also the author of Summa conciliorum et pontificum Petro usque ad Paulum tertium (Salamanca 1551); and Comentarios sobre el catechismo Christiano (Antwerp 1558). The only scholar who has recently included a brief discussion of Carranza's text, as edited by Pereña, is Lupher in Romans in a New World, pp. 82-5. ${ }^{67}$ Carranza, Ratione fidei, p. 40. Carranza's rejection of the Roman title is also pointed out in Lupher, Romans in a New World, p. 85.
} 
other than those that they have, they cannot be compelled to that, because they have their own laws and do not want others. ${ }^{68}$

Carranza here vehemently denied that the ius praedicandi could be enforced in infidel territories over which no Christian prince had any authority. Rather than emphasizing the right to the free propagation of the faith, he stressed, in contrast both to Vitoria and to Soto's early writing, that unbelievers could not even be compelled to listen to preaching. ${ }^{69}$ Moreover, it is remarkable that Carranza openly conceded that his view clashed with the teaching of Aquinas. Rather than deploying the characteristically neo-scholastic strategy of re-interpreting the Summa in a way of positioning one's own stance as a compatible extension of the views of Aquinas, Carranza drew attention to the fact that 'the contrary is argued by Saint Thomas' ${ }^{70}$ As a consequence, he thus insisted that 'if they are infidels who never accepted the faith, about whom we can say that if there was no right to take them up and subject them, then there was no right to retain them'.${ }^{71}$ Read in the context of the 'affair of the Indies', this seems to be an open refutation of any justifications of the Spanish presence in the New World via the ius praedicandi.

As David Lupher rightly observes, 'Carranza also offered a striking extension of Soto's and Vitoria's insistence that the Indians had a right to dominion over their own goods and polities' ${ }^{72}$ And indeed, Carranza argued that

if the Christians are plundered and taken captive by the infidels by just title and if they allow them to dwell with the infidels themselves, as subjects, without an injustice against their faith, in that case the church cannot grant a law which would take away their power and dominium. ${ }^{73}$

\footnotetext{
${ }^{68}$ Carranza, Ratione fidei, pp. 40-2: 'princeps infidelis non potest compelli ad audiendam fidem ... si tota respublica conveniret ut nollint audire aliam fidem, nec alias leges ab illis quas habent, isto non potest compelli, quia ipsi habent suas leges et nollunt alias.'

${ }^{69}$ This is, even with regard to the 'Indian question' more broadly speaking, contra Pagden, Fall of natural man, p. 107: 'his [i.e., Carranza's] conclusion was the same as Vitoria's'.

${ }^{70}$ Carranza, Ratione fidei, p. 42, emphasis mine: 'Contrarium autem divus Thomas intelligit ... possunt principes infidelium ad hoc compelli ut admitant praedicatores.'

${ }^{71}$ Ibid.: 'si sunt infideles qui nunquam susceperunt fidem, de illis dicendum est quod si non habuerunt ius ad eos suscipiendos, nec habent ad detinendos illos'.

${ }^{72}$ Lupher, Romans in a New World, p. 85.

${ }^{73}$ Carranza, Ratione fidei, p. 47: 'si christiani justo titulo expolientur ab infidelibus et capiantur ab infidelibus et permittunt habitare sine iniuria suae fidei etiam subditi cum ipsis infidelibus, in tali casu ecclesia non potest concedere legem quae illos eximat ab eorum potestate et dominio'.
} 
Unbelievers, in Carranza's view, had the same rights as Christians and could therefore indeed justly wage a war against Christians if they had a just cause. At the same time, however, Carranza strongly emphasized the importance of the integrity of the Christian faith. Amerindians could only make use of their just title if they did not thereby hinder the Christian faith, and this testifies to an ambiguous convergence between rights and the faith insofar as a violation of the latter voided the former.

Most importantly, however - and this is entirely ignored by Lupher - Carranza sidestepped the issue of the injustice involved in Spain's 'acquisition' of authority over American Indians. Although they had 'unjustly' accepted the faith, 'the pope must care for those, or even more, he must entrust this care to a Catholic prince, so that these [Amerindians] do not return into unbelief' ${ }^{74}$ Consequently, he insisted that 'muchos indios ${ }^{75}$ had already become members of the Christian church and, irrespective of the circumstances of their integration, the effect was that this gave the pope an obligation to 'care' for the American Indians. According to the neo-scholastic logic, apostates will suffer from eternal damnation and must therefore be saved, and Carranza's point about the pope's 'care' thus has to be conceived as serious, theological reasoning. At the same time, however, Carranza avoided engaging the question whether the fact that conversion had not gone about peacefully and not by the free will of the neophytes problematized the situation in any way. Instead, he remained silent about whether the ius praedicandi could have justified the conquest in the first place and thereby avoided any further conflation of nature and grace. Carranza was far from challenging the de facto state of Spanish authority over the New World, but his elusive stance testifies to the uneasy position of the ius praedicandi and the Christian faith within a system of natural rights that was otherwise clearly independent of Christianity. In order to understand the underlying force of Carranza's argument, we now turn to Melchor Cano, who understood the ius praedicandi in the same terms but, unlike Carranza, further articulated its implications. ${ }^{76}$

Shortly before moving to Salamanca to succeed his former master Francisco de Vitoria as prime chair in theology, Melchor Cano addressed the question of the justice of

\footnotetext{
${ }^{74}$ Ibid., p. 42: 'Alii sunt infideles qui susceperunt fidem, licet iniuste como muchos indios, de his dicendum est, quod Pontifex debet habere curam, imo debet committere principi christiano qui curet ne illi redeant ad vomitum'.

${ }^{75}$ See the quote in the previous footnote.

${ }^{76}$ The point is that both were speaking the very same language or discourse. On the relationship between author and discourse, see Quentin Skinner, 'Interpretation and the understanding of speech acts', in Visions of politics (3 vols., Cambridge, 2002), I, pp. 117-8.
} 
Spanish authority in the New World in one of his final lectures delivered at the University of Alcalá in $1546 .{ }^{77}$ In De dominio indorum Cano insisted, like Carranza before him, that if unbelievers impeded the Christians' preaching of the faith, they could not therefore be compelled to listen. ${ }^{78}$ Importantly, Cano at the same time emphasized that this was only so if all unbelievers stood united in their opposition to preaching. Yet, he went on, 'because it is likely that some of these people want to listen and are prevented by tyrants, it is licit to attack by war. Not by reason of the gospel, but in order to defend the innocent'.$^{79}$ In arguing that there would always be people who did give ear to preaching, Cano made explicit that the ultimate justification of the Spanish presence was not based on grace, but framed by the language of natural rights. However, he did not thereby diminish the power of the ius praedicandi. On the contrary, it was the very right to preach the Gospel whose prevention gave rise to the right to defend the innocent.

While Carranza had only discussed the consequence of the particular situation if the entire commonwealth agreed that they do not want to hear about another faith', ${ }^{80}$ as we have seen, Cano emphasized that this was merely a theoretical assertion which was never actually likely to take place and which could not therefore be an appropriate description of the situation in the New World. In contrast to Carranza's elusiveness about the role the ius praedicandi played in theorizing Spanish authority over American Indians, Cano pondered on its further implications. He thus established a crucial link between the ius praedicandi and what ultimately turned out to be the right to wage a war (ius belli), thereby deploying a fullyfledged theoretical legitimation of the Spanish conquest of the New World. ${ }^{81}$ What Cano was actually doing can therefore hardly be characterized as 'not the reaping of opportunities offered by traditional ius belli' and, instead, championing 'the liberation of the oppressed from the shackles of tyrannical enemies', 82 as David Lupher insists.

\footnotetext{
${ }^{77}$ Lupher, Romans in a New World, p. 85. Cano's opus magnum is his De locis theologicis (Salamanca 1563), which went through 30 editions until the end of the nineteenth century (see Schmutz's entry on Cano on Scholasticon; and for the wider context of the De locis theologicis see Plans, La escuela de Salamanca, pp. 54972.)

${ }^{78}$ Melchor Cano, De dominio indorum, Latin ed. with parallel Spanish trans. by Luciano Pereña, in Misión de España en América: 1540-1560, by Luciano Pereña (Madrid, 1956), a. 14, p. 142.

${ }^{79}$ Ibid., emphasis mine: 'quia verisimile est aliquos e populo velle audire et impediuntur a tyrannis, licet bello petere, non ratione evangelii, sed in defensionem innocentium'.

${ }^{80}$ See above at footnote 68.

${ }^{81}$ The very same argument was later also deployed by Pedro de Sotomayor, Soto's successor as prime chair of theology at Salamanca, in his lecture course on Aquinas's Summa in 1556-7. See Pedro de Sotomayor, An sola causa augendi religionem et fidem liceat contra infideles bellare qui non possident terras nostras nec intulerunt nobis aliquid malum, in De bello contra insulanos: intervención de España en América: escuela española de la paz, segunda generación 1560-1585, by Juan de la Peña, ed. Luciano Pereña et al. (Madrid, 1982), p. 182. ${ }^{82}$ Lupher, Romans in a New World, p. 85.
} 


\section{III}

Let us now return to Domingo de Soto, and explore his engagement with the ius praedicandi in two of his later writings. De dominio, as we know, does not provide a comprehensive answer as to how Soto situated the ius praedicandi in his response to the 'affair of the Indies'. In one of his later relectiones, a lecture delivered at the University of Salamanca in 1554 , Soto addressed the matter anew, raising the question whether infidel commonwealths could be justly conquered on the grounds of their idolatry..$^{83}$ Although only a fragment of it has survived, it is a noteworthy text insofar as Soto here took a position that differed strikingly from his earlier argument in De dominio. His main thrust was 'to show that solely on account of their infidelity, the Christians do not have the right to wage war against the infidels, and this is because we do not have such a power ... the Catholic faith has not given us any power to punish them' ${ }^{84}$ Soto here suggested a clear cut separation of matters of the faith from temporal power and the language of natural law. ${ }^{85}$ But Soto also no longer referred to the right to preach the gospel, and he thereby avoided addressing the problematic status of the ius praedicandi, and how it might or might not be enforced if Christian preaching was to be faced with opposition.

But this is not the end of the story. It was in his final great work, a commentary on the fourth book of Peter Lombard's Sentences, first published in two volumes between 1558-60, in which Soto finally came to address the matter more comprehensively. ${ }^{86}$ This text remains largely absent from any modern scholarly discussion of Soto's political thought, ${ }^{87}$ which may be due to the fact that In quartum sententiarum commentarii was de jure a commentary on the Sentences. A closer look at the text itself, however, makes clear that Soto in fact turned it into a commentary on Aquinas's Summa, and he did this by an 'integration of the articles of

\footnotetext{
${ }^{83}$ The Latin text is edited as An liceat civitates infidelium seu gentilium expugnare ob idolatriam, in De bello contra insulanos: intervención de España en América: escuela española de la paz, segunda generación 15601585, by Juan de la Peña, ed. Luciano Pereña et al. (Madrid, 1982), pp. 586-92.

${ }^{84}$ Soto, An liceat civitates, p. 587: 'monstratum est ob solam idolatriam non esse christianis fas infideles debellare, ea scilicet de causa quod talem potestatem non habemus ... fides catholica nullam nobis tradidit potestatem eadem puniendi'.

${ }^{85}$ Ibid., p. 592: 'Quare non video cur nobis facultatem faciat illos armis reprimendi.' In this sense, it is not quite correct to simply say that Soto 'remained' skeptical, as Richard Tuck argues. See Tuck, Rights of war and peace, p. 75.

${ }^{86}$ For reasons of availability, I am quoting from the edition that was printed in Salamanca in 1569: Domingo de Soto, In quartum sententiarum commentarii (2 vols., Salamanca, 1569).

${ }^{87}$ The major exceptions are Jaime Brufau Prats, La escuela de Salamana, pp. 114-17; and Joseph Höffner, Kolonialismus und Evangelium: Spanische Kolonialethik im Goldenen Zeitalter, 2nd rev. ed. (Tier, 1969), pp. 327-41.
} 
the Summa into the distinctions of the Sentences' ${ }^{88}$ This strategy of Soto's also becomes apparent when considering the section in which he, again, addressed the issue of forcible conversion and in which he finally came to revisit the status of the ius praedicandi. ${ }^{89}$

At the outset of the discussion, Soto reiterated his insistence on the validity of the ius praedicandi, framing it with two fundamental premises: First, 'by the law of nature, anybody has the liberty and right to instruct others and to persuade them of [the Gospel]' ${ }^{90}$ In contrast to the relectio An liceat civitates, Soto brought the ius praedicandi back into play and, for the first time, also clearly insisted that it was a right framed by natural law. We shall return to this point shortly. Secondly, Soto continued, 'if anybody hinders and prevents us from this preaching, we have the right to ward off his violence ... However, we cannot compel those who do not want to listen to us'. ${ }^{91}$ Soto here took up his earlier point made in De dominio, insisting that the ius praedicandi could be enforced insofar as it could be defended. ${ }^{92}$ Yet, his subsequent argument that unbelievers could not therefore be forced to listen to Christian preaching raises the question whether Soto followed Cano's solution - that there would always be those who want to listen; ultimately an argument about the defence of the innocent - thus reconciling this qualification with a conception of the ius praedicandi as enforceable right.

In order to try to answer these issues, let us first turn to a key passage in which Soto addressed the concrete case of the role of the ius praedicandi in the New World:

\begin{abstract}
Alexander VI, by his donation to our Catholic Monarchs Ferdinand and Isabella, conceded the expedition to the Occidental Islands of the infidels. But to this I reply, especially, that the pope did not concede ... and indeed could not have conceded dominium to them..$^{33}$
\end{abstract}

\footnotetext{
${ }^{88}$ Lidia Lanza and Marco Toste, 'The Sentences in sixteenth-century Iberian scholasticism', in Medieval commentaries on the Sentences of Peter Lombard, ed. Philipp W. Rosemann (3 vols., Leiden, 2001-15), III, p. 452. Although Soto had indeed written a more straightforward commentary on the Summa, he did not address q. 10 of the 2a2ae in his famous De iustitia et iure (Salamanca 1553/6).

${ }^{89}$ Soto, In quartum sententiarum, vol. 1, dist. 5, q. unica, a. 10, fol. 265, col. 1.

90 Soto, In quartum sententiarum, vol. 1, dist. 5, q. unica, a. 10, fol. 266, col. 2: 'Iure naturae unusquilibet libertatem habet et facultatem docendi alios, eisque persuadendi illa [i.e., the Gospel].' I am translating facultas as 'right' because, like ius, it was conceived by Soto as 'licit ability' or 'licit subjective power' (see Brett, Liberty, right and nature, p. 150).

${ }^{91}$ Soto, In quartum sententiarum, vol. 1, dist. 5, q. unica, a. 10, fol 267, col. 1: 'Si quis eandem praedicationem nobis impediret et cohiberet, iure possemus eius violentiam, etiam armis, propulsare ... Illos autem, qui nos audire nolent, compellere ut nos audirent, non possemus.'

${ }^{92}$ See above at footnote 61 .

${ }^{93}$ Soto, In quartum sententiarum, vol. 1, dist. 5, q. unica, a. 10, fol. 272, col. 1: 'Quintum argumentum in contrarium afferri potest, quod Alexander sextus suo diplomate catholicis regibus nostris Ferdinando et
} 
Soto here reiterated his earlier position and, indeed, the authentically neo-scholastic view that the papal donation to the Reyes Católicos in 1493 did not grant them any temporal power over the New World, because the pope himself did not have this kind of potestas in the first place. ${ }^{94}$ At the same time, however, he went on to argue that

the pope indeed executes that power over the whole world, which is the promulgation of the faith, and these regions and lands are in his power in order to distribute this office. And therefore, he granted them to the Spanish Kings, so that these send learned and honest men, who teach this very faith..$^{95}$

Interestingly, although Soto had initially argued that everybody had the right to preach the gospel by natural law, he now insisted that this was a particular power of the pope - a power not only over Christian territories, but equally over the lands of the non-apostate infidels in the New World. In his commentary on the Sentences, Soto thus framed the ius praedicandi both as a natural right and as a papal power, which testifies to its uneasy position between rights that are natural and thus apply to anyone, and matters of the faith, which only apply to Christians and do not have an effect over temporal matters. The ius praedicandi thus blurs the categories of natural/Christian and temporal/spiritual, respectively, and cannot be unambiguously situated either within one or the other.

It is undoubtedly true that Soto was far from openly advocating Spanish dominion in the New World on the grounds of the ius praedicandi and problematized forcible conversion in his commentary on the Sentences.$^{96}$ Soto insisted that the Spaniards could only have obtained a right over American Indians 'if by their own will they converted to Christianity and chose the same kings' or 'if they did not persist in the faith, which they had accepted' ${ }^{97}$ And like all the Dominican neo-scholastics, he was indeed wary of granting the pope too much power and opposed a hierocratic papalism. A counter-example might be Alonso de la

\footnotetext{
Elisabeth [sic!] expeditionem in Insulas Occidentales infidelium concessit. Ad hoc autem respondetur in primis pontificem neque concessisse, imo vero neque ... concedere potuisse dominium eorum.'

${ }^{94}$ The same had already been argued by Vitoria, as noted above in Section 2.

${ }^{95}$ Soto, In quartum sententiarum, vol. 1, dist. 5, q. unica, a. 10, fol. 272, col. 1: 'Enimvero cum summus pontifex hac in universum orbem potestas fungatur, quae est fidem promulgare, illi competit regiones plagasque ad hoc munus distribuere. Et ideo concessit Hispaniarum regibus, ut illuc mitterent viros doctos et probos, qui eandem docerent fidem.'

${ }^{96}$ Soto, In quartum sententiarum, vol. 1, dist. 5, q. unica, a. 10, fol. 270, col. 1.

${ }^{97}$ Ibid., fol. 272, col. 1: 'si dum sua se sponte in Christianismum manciparent eosdem sibi reges eligerent ... Deinde si in fide, quam susceperant non persisterent, possent tunc subiugari'.
} 
Vera Cruz (1507-84), who after his studies and a short-term position at Salamanca joined the Augustinian mission, and became professor of theology at the newly established University of Mexico in $1553 . .^{98}$ On the one hand, Vera Cruz agreed with the scholastics in Spain that 'the sovereign pontiff is under obligation ... to send missionaries to the unlettered and primitive peoples recently discovered, inasmuch as they were the sheep of Christ according to the eternal predestination, and he must bring them in' ${ }^{99}$ But he went further than that. Whereas the members of the School of Salamanca unanimously insisted that papal potestas did not extend to direct temporal claims over the natives in the New World, Vera Cruz insisted that 'if necessary', the pope had 'authority and dominion over all things temporal' ${ }^{100}$ Ultimately, he explained, this meant that if the pontiff "could not perform his duty because of some obstacle placed by some king or temporal ruler, he might dispose of such a king and of his kingdom and power, either by depriving him of it, or by punishing him or by waging war against him to the extent necessary to remove the obstacle' ${ }^{101}$

Domingo de Soto, in contrast, refrained from openly arguing that the pope possessed the power to depose princes in the New World, even if Christian preaching was hindered. Moreover, he also opposed the Vitorian view of enforcing the ius praedicandi against the unbelievers' will, and he likewise avoided overtly advocating the underlying link between the ius praedicandi and the right to wage war, as Cano had done. However, in accepting the validity of the ius praedicandi, he could not avoid the fundamental ambiguity that was at the heart of the right to preach the gospel, the very fact that it negotiated both the language of grace and the language of natural law. Although nobody could be forced to listen, the American Indians could neither hinder Spanish preaching without violating the ius praedicandi, whose prevention gave rise to the purely 'secular' right to enforce preaching and ward off any resistance to it. ${ }^{102}$ In this sense, the ius praedicandi served to protect and sustain an enduring state of Christian preaching, up to the moment of the Amerindians' conversion. And after their incorporation into the church, the Spaniards would finally have rightful authority over the peoples in the New World.

\footnotetext{
${ }^{98}$ On the biographical and intellectual context of Vera Cruz, see Schmutz's entry on Scholasticon; and Ernest J. Burrus, 'Introduction', in The writings of Alonso de la Vera Cruz, ed. Ernest J. Burrus (5 vols., Rome, 1967-76), II, pp. 7-14. On Vera Cruz' engagement with the Roman imperial title, see Lupher, Romans in a New World, pp. $161-7$.

${ }^{99}$ Alonso de la Vera Cruz, Reddite Caesaris Caesari et quae Dei sunt Deo, trans. Ernest J. Burrus as Defense of the Indians: their rights, in The writings of Alonso de la Vera Cruz, ed. Ernest J. Burrus (5 vols., Rome, 196776), II, p. 313.

100 Vera Cruz, Reddite Caesaris Caesari, trans. Burrus, II, p. 313.

${ }^{101}$ Ibid., p. 315.

102 Soto, In quartum sententiarum, vol. 1, dist. 5, q. unica, a. 10, fol. 272, col. 1.
} 
Advocates of empire or critics, who unmasked the faulty foundation of Castilian domination in the Americas? Charles V reprimanded the neo-scholastics for their inquiries into the legitimacy of the conquest, as we have seen, and not everything the Spanish theologians said seems quite in line with the voice and venture of the emperor. This is especially so if we focus on classical Roman arguments. Much recent work in intellectual history has highlighted those neo-scholastic topoi, which cast doubt on the School of Salamanca's imperial complicity. Yet the fact that the neo-scholastics opposed traditional arguments for empire was not the end of their story, and it should neither be the end of ours. Post-colonial readings of the Thomist responses to the 'affair of the Indies', though often deemed and doomed as anachronistic, have suggestively underlined the importance of looking for empire where we might not anticipate it at first sight. In shifting the focus toward the right to preach the gospel, this article has tried to make a case for the importance of this latter notion, without abandoning the conviction that historical discourses must be understood in the terms that past thinkers themselves were using.

To be sure, appeals to the nexus of preaching and empire were not limited to the political thought of the Spanish scholastics. At the end of the sixteenth century, for instance, the Italian intellectual Giovanni Botero emphasized the importance of religious instruction in the New World by relating the situation in Spanish America to the historically intimate relationship between the Roman empire and the Catholic church. ${ }^{103}$ 'The greatness of empire', Botero wrote, 'signifies much for the preaching of the gospel of peace, for to empire alone is peace conjoined. ${ }^{104}$ While Botero did not speak of a right of preaching in the way that the Spanish theologians did, in his thought Christian mission was ultimately 'a function of empire', ${ }^{105}$ too. The neo-scholastic theorizations of the ius praedicandi thus constitute a distinct episode within a broader history of early modern reflections on the entanglement of European power overseas and the Catholic church.

What is more, to some extent, the ius praedicandi negotiates Spanish authority in the New World in a way that is analogous to the more well-known right of free communication (ius communicandi). Missionaries as well as merchants had a right to enter Amerindian commonwealths, and in both cases a refusal of letting them pass would amount to a just

\footnotetext{
${ }^{103}$ I thank the anonymous reviewer for pointing me to Botero.

${ }^{104}$ Giovanni Botero, Relationi universali (Venice 1622), part 4, bk. 2, p. 12, trans. in John M. Headley, 'Geography and empire in the late Renaissance: Botero's assignment, western universalism, and the civilizing process', Renaissance Quarterly, 53.4 (2000), pp. 1119-55, at p. 1137.

${ }^{105}$ Headley, 'Geography and empire', p. 1137.
} 
Spanish war. But while both of these legal mechanisms can be said to belong to a broader arsenal of more or less straightforwardly imperial legal commonplaces, the argument of this article is that the ius praedicandi is unique insofar as it is qualitatively different from alternative arguments for empire. In many ways, the Spanish theologians sought to make sense of the issues involved in the New World by relating them to familiar examples from a European setting. Vitoria, as we have seen, asserted that the Spaniards had a right to travel to the Indies in the same way that they could justly penetrate the kingdom of France. This articulation of juridical arguments in a set of diverse contexts that often cut across the Atlantic - something Annabel Brett has called 'the Dominican habit of "crossreferencing"" 106 - is a well-known and indeed crucial hermeneutic strategy of the Salmantine theologians. The ius praedicandi, however, embodied an oddly regional element that militated against the very universality of natural law of which it was also a constitutive part. It became a specifically pressing issue for the Spanish scholastics because the peoples in the New World were non-apostate unbelievers, who had never been subject to Christian-Roman princes. The discussion about the enforceability of the right to preach the gospel, therefore, could not be domesticated and was clearly set in an exclusively overseas context. ${ }^{107}$ It is in this sense that the ius praedicandi also constitutes an expressly imperial locus.

In its sliding between natura and gratia this right is equally suggestive and indicative of the underappreciated complexity of Spanish scholastic thought. The reluctant, cautious, and at times elusive ways of addressing the ius praedicandi testify to the fact that the neoscholastic theologians, and most significantly Domingo de Soto, were well aware that it did not sit easily with the idea of natural rights. It provided an ambiguous interface, a grey area between nature and the faith, and between temporal and spiritual power. The ius praedicandi thus served to translate the neo-scholastics' deeply rooted belief in the hegemonic truth of the Christian faith into a discourse of otherwise 'secular' rights and therefore provided a normative justification for spreading Christianity. In the context of the 'affair of the Indies', however, its ultimate effect was to pave a direct way for establishing Spanish empire, the right to demand obedience, in the New World.

\footnotetext{
${ }^{106}$ Brett, 'Scholastic political thought', p. 145. See also Brett, Changes of state, ch. 1.

${ }^{107}$ I do not therefore agree with Anthony Pagden that in Vitoria's logic, 'this would mean that Indian missionaries - should such persons have existed - or far more contentiously Muslim ones, should have been allowed a similar access to Spain' (Burdens of empire, p. 65). In the scholastic understanding, the ius praedicandi was not about preaching any religion, but uniquely about spreading the Christian faith.
} 